\title{
TRITERPENES AND ANTITUBERCULAR ACTIVITY OF Byrsonima crassa
}

Celio Takashi Higuchi, Fernando Rogério Pavan e Clarice Queico Fujimura Leite*

Departamento de Ciências Biológicas, Faculdade de Ciências Farmacêuticas, Universidade Estadual Paulista, Rodovia AraraquaraJaú, km 1, 14801-902 Araraquara - SP, Brasil

Miriam Sannomiya e Wagner Vilegas

Departamento de Química Orgânica, Instituto de Química, Universidade Estadual Paulista, Rua Francisco Degni, s/n, 14800-900 Araraquara - SP, Brasil

Sergio Roberto de Andrade Leite

Departamento de Química Geral e Inorgânica, Instituto de Química, Universidade Estadual Paulista, Rua Francisco Degni, s/n, 14800-900 Araraquara - SP, Brasil

Luis Vitor S. Sacramento

Departamento de Princípios Ativos Naturais e Toxicologia, Faculdade de Ciências Farmacêuticas, Universidade Estadual Paulista, Rodovia Araraquara-Jaú, km 1, 14801-902 Araraquara - SP, Brasil

Daisy Nakamura Sato

Instituto Adolfo Lutz de Ribeirão Preto, Rua Minas, 877, 14085-410 Ribeirão Preto - SP, Brasil

Recebido em 7/12/07; aceito em 8/5/08; publicado na web em 19/9/08

\begin{abstract}
We evaluated the potential antitubercular activity of triterpenes obtained from leaves and bark of Byrsonima crassa. From chloroform extracts of the leaves, by bioassay-guided fractionation, we obtained mixtures of known triterpenes: $\alpha$-amyrin, $\beta$-amyrin and their acetates, lupeol, oleanolic acid, ursolic acid and $\alpha$-amyrinone. Tested against Mycobacterium tuberculosis, the triterpenes exhibited minimum inhibitory concentrations (MICs) of $31.25-312.25 \mu \mathrm{g} / \mathrm{mL}$. $\beta$-amyrin and friedelin, isolated from the chloroform extract of bark, showed MICs of 312.25 and $125 \mu \mathrm{g} / \mathrm{mL}$ respectively. This is the first report of the identification and determination of the activity of $B$. crassa triterpenes against $M$. tuberculosis.
\end{abstract}

Keywords: Byrsonima crassa; antitubercular activity; triterpenes.

\section{INTRODUCTION}

Tuberculosis (TB) remains an important public health problem worldwide, causing the deaths of about 1.6 million people each year. According to the World Health Organization, it is estimated that 8.8 million new TB cases occurred in 2007. ${ }^{1}$ Despite the improvements in chemotherapy, TB control is severely affected by the development of multidrug resistant $M$. tuberculosis strains. ${ }^{2-4}$ The urgent need to create or find new drugs to reduce the global burden of tuberculosis is much discussed in the current biomedical literature. ${ }^{5,6}$ Natural products and/or their semi-synthetic derivatives can lead to compounds and may play important roles in the treatment of TB. ${ }^{7}$ A review of plant terpenoids showed moderate to significant biological activity against $M$. tuberculosis. ${ }^{2}$

Byrsonima crassa Niedenzu (IK) (Malpighiaceae) is a native specie of the Brazilian Cerrado (savannah-like vegetation). $B$. crassa is popularly known in Brazil as "murici-cascudo" or "muricivermelho". ${ }^{8}$ Several medicinal properties are attributed to the bark and leaves of this species. It is used in Brazilian folk medicine for the treatment of diseases related mainly to peptic ulcer. ${ }^{8}$ In earlier papers we have reported the antiulcer activity and the chemical composition of the methanol and hydromethanol extracts of B. crassa..$^{9-11}$ Despite its popular use as a medicinal plant, no data have been published on the antitubercular activity of leaf and bark extracts of this species, and we have found no report on the chemical composition of the nonpolar chloroform extract of this plant.

The aim of the present study was to identify the nonpolar com- pounds present in the leaves and bark of Byrsonima crassa and to determine the antitubercular activity of their enriched fractions and isolated compounds.

\section{EXPERIMENTAL}

\section{General experimentation procedures}

Analytical and preparative thin layer chromatography (TLC) were carried out on Kieselgel 60-precoated Al sheets ( $0.2 \mathrm{~mm}$, Merck) and column chromatography was performed on silica gel (70-230 mesh, Merck). The TLC spots were visualized by spraying with $10 \% \mathrm{H}_{2} \mathrm{SO}_{4}$ in water, followed by heating at $110{ }^{\circ} \mathrm{C}$.

The NMR spectra in $\mathrm{CDCl}_{3}$ were acquired with a Varian INOVA 500 spectrometer, operating at $500 \mathrm{MHz}$ for ${ }^{1} \mathrm{H}$ and $150 \mathrm{MHz}$ for ${ }^{13} \mathrm{C}$. Chemical shifts were given in $\delta$ (ppm), using tetramethylsilane (TMS) as internal standard.

The compounds were identified by NMR as described by Olea and Roque ${ }^{12}$ and structures were confirmed by comparison against literature spectroscopic data ${ }^{13-16}$ (Figure 1).

\section{Plant material}

Leaves and bark of B. crassa Niedenzu (IK) were collected at Porto National, Tocantins State, Brazil ( $\left.10^{\circ} 42^{\prime} \mathrm{S}, 48^{\circ} 24^{\prime} \mathrm{W}\right)$, and identified by Dr. E. R. dos Santos. A voucher specimen ( $\left.n^{\circ} 3377\right)$ was deposited at the herbarium of the Universidade de Tocantins. 


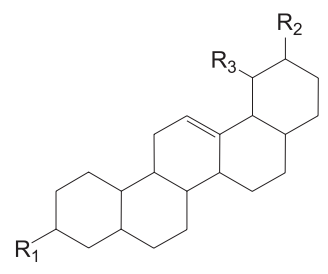

$\mathrm{R} 1=\mathrm{OH}, \mathrm{R} 2=\mathrm{CH} 3, \mathrm{R} 3=\mathrm{H}: \quad \beta$-amyrin $\mathrm{R} 1=\mathrm{OAC}, \mathrm{R} 2=\mathrm{CH} 3, \mathrm{R} 3=\mathrm{H}: \beta$-amyrin acetat $\mathrm{R} 1=\mathrm{OH}, \mathrm{R} 2=\mathrm{H}, \mathrm{R} 3=\mathrm{CH} 3: \alpha$-amyrin $\mathrm{R} 1=\mathrm{OAc}, \mathrm{R} 2=\mathrm{H}, \mathrm{R} 3=\mathrm{CH} 3$ : $\alpha$-amyrin acetate

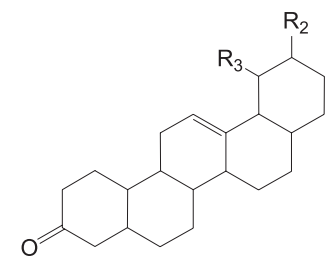

$\mathrm{R} 2=\mathrm{H}, \mathrm{R} 3=\mathrm{CH} 3: \alpha$-amyrinone

Figure 1

\section{Extraction and isolation}

The ground materials (1.8 kg bark; $2.0 \mathrm{~kg}$ leaves) were subjected to exhaustive extraction with chloroform at room temperature for $48 \mathrm{~h}$. Solvent was evaporated at $60{ }^{\circ} \mathrm{C}$ under reduced pressure, affording the crude leaf extract (53.8 g) and the crude bark extract (14.1 g).

\section{Leaves}

The chloroform leaf extract (33.4 g) was subjected to column chromatography $(\mathrm{CC})$ on silica gel $(32.0 \times 3.0 \mathrm{~cm}$ i.d. $)$ to obtain fractions of rising polarity by elution with $n$-hexane, dichloromethane and methanol, in this order. Evaporation of the solvents resulted in hexane $(168 \mathrm{mg})$, dichloromethane $(10.0 \mathrm{~g})$, and methanol $(4.0 \mathrm{~g})$ dry fractions. The hexane fraction (HF,168 $\mathrm{mg}$ ), applied to a silica gel column $(12 \times 2.0 \mathrm{~cm}$ i.d. $)$ and eluted with $n$-hexane, furnished the acetates of $\beta$-amyrin and $\alpha$-amyrin (108 $\mathrm{mg}$ ). The dichloromethane fraction (DF,10.0 g), also subjected to CC (silica gel, $n$-hexane-EtOAc mixtures, in order of increasing polarity), afforded 49 fractions. Fractions $1-2(158 \mathrm{mg})$ were loaded on a new silica gel column (14.0 x $2.0 \mathrm{~cm}$ i.d.) and eluted with $n$-hexane-chloroform (75:15), yielding a mixture of $\alpha$-amyrinone, lupeol and $\beta$-amyrin $(10.0 \mathrm{mg}$ ). Fractions 8-10 $(227 \mathrm{mg})$ were also rechromatographied on a silica gel column $(6.0 \times 2.0 \mathrm{~cm}$ i.d. $)$, yielding a mixture of $\beta$-amyrin and $\alpha$-amyrin (36.0 mg).

The methanol fraction (MF4.0 g) was fractionated by CC on silica gel $(18 \times 3.5 \mathrm{~cm}$ i.d.), eluted with mixtures of $n$-hexane and EtOAc of increasing polarity. 56 fractions were collected, of which 37-56 were combined ( $225 \mathrm{mg}$ ), applied to a silica gel CC and eluted with $n$-hexane-EtOAc (70:30). This last yielded a mixture of ursolic and oleanolic acids $(36.0 \mathrm{mg})$.

\section{Bark}

The chloroform extract of the bark $(5.8 \mathrm{~g})$ was subjected to CC on silica gel $(32 \times 5.0 \mathrm{~cm}$ i.d.) using a gradient of $n$-hexane-EtOAc of rising polarity. The 99 eluted fractions ( $100 \mathrm{~mL}$ each) were combined to give 21 fractions. Fractions 31-34 yielded the triterpene friedelin as a white crystal $(530 \mathrm{mg}$ ), while fractions $39-40$ furnished $\beta$-amyrin $(2.4 \mathrm{~g})$ as a pure white crystal.

\section{Determination of antitubercular activity}

Antitubercular activity of extracts and fractions diluted in DMSO was determined against Mycobacterium tuberculosis $\mathrm{H}_{37} \mathrm{Rv}$ ATCC 27294, using the microplate Alamar Blue assay (MABA), as recommended and validated by Collins and Franzblau. ${ }^{17}$ The minimal inhibitory concentration (MIC) of the compound was defined as the concentration necessary to inhibit $90 \%$ of the mycobacterial growth in sterile 96-well plates (Falcon 3072; Becton Dickinson, Lincoln Park, NJ). Fluorescence was measured in a Spectrafluor Plus microfluorimeter (Tecan) in bottom reading mode, with excitation at 530 $\mathrm{nm}$ and emission at $590 \mathrm{~nm}$. A sample with a MIC value $<125 \mu \mathrm{g} / \mathrm{mL}$ was defined as active against M. tuberculosis. ${ }^{18}$ As a standard control, the MIC value of isoniazid was determined on each microplate. The acceptable MIC of isoniazid ranged from 0.015 to $0.05 \mu \mathrm{g} / \mathrm{mL} .{ }^{17}$

\section{RESULTS AND DISCUSSION}

Investigation of traditionaly used medicinal plants is an efficient way of searching for new candidate chemotherapeutic drugs. Plant extracts are an attractive source of new drugs, and bioassay-guided fractionation facilitates the isolation of active principles contained in crude natural products.

In a previous study of $B$. crassa, Cardoso et al. ${ }^{19}$ showed that its methanol extract was mutagenic to Salmonella typhimurium TA 98, but the chloroform extract was devoid of this activity.

The B. crassa chloroform extracts (MICs of $312.25 \mu \mathrm{g} / \mathrm{mL}$ for bark and $125 \mu \mathrm{g} / \mathrm{mL}$ for leaves) were fractionated resulting in the identification of nine previously known compounds (Figure 1), whose MICs were measured (Table 1). The hexane fraction (HF) of the leaf extract yielded a mixture of $\alpha$-amyrin and $\beta$-amyrin acetates (MIC $31.25 \mu \mathrm{g} / \mathrm{mL}$ ). The dichloromethane fraction (DF) gave a mixture of lupeol, $\alpha$-amyrinone and $\beta$-amyrin (MIC $312.5 \mu \mathrm{g} / \mathrm{mL}$ ) and a mixture of $\alpha$-amyrin and $\beta$-amyrin (MIC $31.25 \mu \mathrm{g} / \mathrm{mL}$ ). The methanol fraction (MF) yielded the triterpenes oleanolic and ursolic acids (MIC of $62.5 \mu \mathrm{g} / \mathrm{mL}$ ). In the $5.8 \mathrm{~g}$ of chloroform bark extract, $2.4 \mathrm{~g}$ of pure $\beta$-amyrin (MIC $312.25 \mu \mathrm{g} / \mathrm{mL}$ ) and $530 \mathrm{mg}$ of friedelin (MIC 125 $\mu \mathrm{g} / \mathrm{mL}$ ) were found.

Table 1. MIC values of isoniazid, choroform extracts and fractions of $B$. crassa against $M$. tuberculosis, determined by MABA

\begin{tabular}{lc}
\hline Samples & $\mathrm{MIC}(\mu \mathrm{g} / \mathrm{mL})$ \\
\hline bark choroform extract & 312.25 \\
$\beta$-amyrin & 312.25 \\
friedelin & $\mathrm{ND}^{*}$ \\
leave choroform extract & 62.5 \\
mixture of ursolic and oleanolic acid & 62.5 \\
mixture of lupeol, $\alpha$-amyrenone and $\beta$-amyrin & 312.25 \\
mixture of $\alpha$-amyrin and $\beta$-amyrin & 31.25 \\
mixture of $\alpha$-amyrin and $\beta$-amyrin acetates & 31.25 \\
Reference drug & \\
Isoniazid & 0.03 \\
\hline
\end{tabular}

*ND - not done

According to Copp ${ }^{20}$ secondary metabolites of terpenoid origin are among the most promising classes of natural products with antimycobacterial activity.

Akihisa et al. ${ }^{21}$ found a MIC against $M$. tuberculosis higher than $64 \mu \mathrm{g} / \mathrm{mL}$ for $\alpha$-amyrin and for $\beta$-amyrin isolated from Asteraceae flowers. The MIC value of $31.25 \mu \mathrm{g} / \mathrm{mL}$ determined here for the mixture of $\alpha$-amyrin and $\beta$-amyrin is better than the MIC of either 
compound in isolation, probably indicating their synergist action in the mixture. The MIC of $312.25 \mu \mathrm{g} / \mathrm{mL}$ for pure $\beta$-amyrin, found in the current work, reinforces this conclusion. This high MIC value disqualifies this compound, present in large amounts in the bark of $B$. crassa, as a tuberculostatic drug. However, considering the great intensification of its tuberculostatic effect when mixed with its $\alpha$ isomer, it should be possible to increase its activity by appropriate structural alterations. ${ }^{7}$

The mixture of lupeol, $\alpha$-amyrinone and $\beta$-amyrin had the MIC of $312.25 \mu \mathrm{g} / \mathrm{mL}$. Wachter et al., ${ }^{22}$ studying the lupeol isolated from Chuquiraga ulcina (Argentina), found a MIC of $64 \mu \mathrm{g} / \mathrm{mL}$. The MIC of the mixture of oleanolic and ursolic acids in the present work was of $62.5 \mu \mathrm{g} / \mathrm{mL}$. According to Caldwell et al..$^{23}$ oleanolic acid has a MIC of $16 \mu \mathrm{g} / \mathrm{mL}$. Cantrell et al. ${ }^{2}$ obtained a MIC of $50 \mu \mathrm{g} / \mathrm{mL}$ for ursolic acid. Gu et al. ${ }^{18}$ also obtained a better MIC value for oleanolic acid (MIC of $28.7 \mu \mathrm{g} / \mathrm{mL}$ ) than for ursolic acid (MIC of $41.9 \mu \mathrm{g} / \mathrm{mL}$ ). In these last examples, each isolated compound exhibited a better MIC than the mixture.

According to Cantrell et al., ${ }^{2}$ isolated compounds that exhibit a MIC of $64 \mu \mathrm{g} / \mathrm{mL}$ or lower are considered promising. For crude extracts, the MIC should be equal to or lower than $125 \mu \mathrm{g} / \mathrm{mL} .{ }^{18}$ Thus, the values of $62.5 \mu \mathrm{g} / \mathrm{mL}$ for the mixture of oleanolic and ursolic acids and of $31.25 \mu \mathrm{g} / \mathrm{mL}$ for the mixture of $\alpha$-amyrin and $\beta$-amyrin and its acetates, obtained here, are as good as a promising isolated compound. Although the MIC values obtained here are larger than that of isoniazid $(0.03 \mu \mathrm{g} / \mathrm{mL})$, these inhibitory concentrations are comparable to the MIC of pyrazinamide (another first-line antitubercular drug), $20-100 \mu \mathrm{g} / \mathrm{mL} .^{24}$

Concluding, our results suggest that oleanolic acid, lupeol and the mixture of $\alpha$ - and $\beta$-amyrin are involved in the antitubercular activity of the chloroform extract of $B$. crassa leaves. The high lipophilicity of terpenes is probably the main factor that allows their penetration through the mycobacterial cell wall.

\section{ACKNOWLEDGMENTS}

We thank the Fundação de Amparo à Pesquisa do Estado de São Paulo (FAPESP) for grants awarded to M. Sannomiya and F. R. Pavan, and for funding from the Biota-Fapesp Program. The grammar and spelling of the text was proof-read by T. J. Roberts, MSc (Lu).

\section{REFERENCES}

1. http://whqlibdoc.who.int/hq/2007/WHO_HTM_TB_2007.378_eng.pdf, acessed in November 2007.

2. Cantrell, C. L.; Franzblau, S. G.; Fischer, N. H.; Planta Med. 2001, 67, 1.

3. Pietro, R. C. L. R.; Kashima, S.; Sato, D. N.; Januario, A. H.; França, S. C.; Phytomedicine 2000, 7, 335.

4. Januario, A. H.; Filho, E. R.; Pietro, R. C.; Kashima, S.; Sato, D. N.; França, S. C.; Phytotherapy Research 2002, 16, 445.

5. Andries, K.; Verhasselt, P.; Guillemont, J.; Göhlmann, H. W.; Neefs J. M.; Winkler, H.; Van Gestel, J.; Timmerman, P.; Zhu, M.; Lee, E.; Williams, P.; de Chaffoy, D.; Huitric, E.; Hoffner, S.; Cambau, E.; Truffot-Pernot, C.; Lounis, N.; Jarlier, V.; Science (Washington, DC, U. S.) 2005, 307, 223.

6. Tripathi, R. P.; Tewari, N.; Diwivedi, N.; Tiwari, V. K.; Medicinal Research Reviews 2005, 25, 95.

7. Cechinel Filho, V.; Yunes, R. A.; Quim. Nova 1998, 2, 99.

8. Silva, S. R.; Silva, A. P.; Munhoz, C. M.; Silva Júnior, M. C.; Medeiros, M. B.; Guia de Plantas do Cerrado Utilizadas na Chapada dos Veadeiros, $1^{\mathrm{a}}$ ed., Planaltina: Brasília, 2001.

9. Sannomiya, M.; Rodrigues, C. M.; Coelho, R. G.; dos Santos, L. C.; Hiruma-Lima, C. A.; Souza Brito, A. R.; Vilegas, W.; J. Chromatogr., A 2004, 1035, 47.

10. Sannomiya, M.; Fonseca, V. B.; da Silva, M. A.; Rocha, L. R.; dos Santos, L. C.; Hiruma-Lima, C. A.; Souza Brito, A. R.; Vilegas, W.; J. Ethnopharmacology 2005, 97, 1.

11. Sannomiya, M.; Montoro, P.; Piacente, S.; Pizza, C.; Brito, A. R. M. S.; Vilegas, W.; Rapid Commun. Mass Spectrom. 2005, 19, 2224.

12. Olea, R. S. G.; Roque, N. F.; Quim. Nova 1990, 13, 278

13. Mahato, S. B.; Kundu, A. P.; Phytochemistry (Elsevier) 1994, 37, 1517.

14. Kikuchi, T.; Yokoi, T.; Niwa, M.; Shingu, T.; Chem. Pharm. Bull. 1977, $25,2078$.

15. Pant, P.; Rastogi, R. P.; Indian J. Chem., Sect. B: Org. Chem. Incl. Med. Chem. 1977, 15, 911 .

16. Hopkins, B. J.; Scheinmann, F.; Phytochemistry (Elsevier) 1971, 10, 1956.

17. Collins, L.; Franzblau, S. G.; Antimicrob. Agents Chemother. 1997, 41, 1004.

18. Gu, J. Q.; Wang, Y.; Franzblau, S. G.; Montenegro, G.; Yang, D.; Timmermann, B. N.; Planta Med. 2004, 70, 509

19. Cardoso, C. R.; de Syllos Cólus, I. M.; Bernardi, C. C.; Sannomiya, M.; Vilegas, W.; Varanda, E. A.; Toxicology 2006, 225, 55.

20. Copp, B. R.; Nat. Prod. Rep. 2003, 20, 535

21. Akihisa, T.; Franzblau, S. G.; Ukiya, M.; Okuda, H.; Zang, F.; Yasukawa, T.; Suzuki, T.; Kimura, Y.; Biol. Pharm. Bull. 2005, 28, 158.

22. Wachter, G. A.; Valcic, S.; Flagg, M. L.; Franzblau, S. G.; Montenegro, G.; Suarez, E.; Timmermann, B. N.; Phytomedicine 1999, 6, 341.

23. Caldwell, C. G.; Franzblau, S. G.; Suarez, E.; Timmermann, B. N.; J. Nat. Prod. 2000, 63, 1611.

24. http://www.accessmed.msf.org/campaign/tb01.shtm, acessed in November 2007. 